\title{
Inheritance of temperature-dependent string formation in common bean (Phaseolus vulgaris L.)
}

\author{
E. Drijfhout
}

Institute for Horticultural Plant Breeding (IVT), Wageningen, the Netherlands

Key words: common bean, Phaseolus vulgaris, genetics, string formation, temperature

\section{Summary}

The inheritance of string development in bean pods was studied, particularly that of incomplete string occurring in some cultivars and promoted by high temperature. String formation was analysed in $F_{1}, F_{2}$ and $F_{3}$ of crosses between cultivars without string, with incomplete string and with complete string, and in $F_{1}$ and $F_{2}$ of a backcross of the hybrid between a stringless and a stringy cultivar to the stringless parent. Besides the gene $S t$, whose dominant allele governs stringlessness and whose recessive alleles condition the development of a complete string, a second gene exists, whose dominant allele, if present with $S t$, governs the formation of an incomplete string. The strength of that string was promoted by high temperature, $23{ }^{\circ} \mathrm{C}$ against $17^{\circ} \mathrm{C}$, but may be inhibited by the genetic background. Symbol Ts is proposed for this second gene, which governs the temperature-dependent incomplete string formation.

\section{Introduction}

Complete string in common bean was found to be governed by a recessive gene st (Prakken, 1934). Drijfhout (1970) divided bean cultivars into three groups on the basis of string: (1) cultivars practically without string formation, on which temperature had no influence; (2) cultivars with incomplete string, the string being stronger at a higher temperature; (3) cultivars with a completely developed string, whose formation was not influenced by temperature. This classification made it necessary to study again the inheritance of string formation, as no data were published on the inheritance of incomplete string.

\section{Material and methods}

The following cultivars were used as parents for the crosses: 'Bush Blue Lake' (practically no string, not temperature-dependent), abbreviated BBL; 'Troef' (incomplete string, depending on temperature), 'Vroege Wagenaar met draad' (com- 
plete string, not temperature-dependent), abbreviated 'Wagenaar' and IVT 7309, a line selected for complete string from the cross BBL $\times$ Wagenaar.

The crosses and their generations analysed for string development were:

$\begin{array}{llll}1 & \text { BBL } & \times \text { Troef } & \text { and reciprocal, } F_{1}, F_{2}, F_{3} \text { lines } \\ 2 & \text { BBL } & \times \text { Wagenaar } & \text { and reciprocal, } F_{1}, F_{2}, F_{3} \text { lines } \\ 3 & \text { BBL } & \times \text { IVT } 7309 & \text { and reciprocal, } F_{1}, F_{2}, F_{3} \text { lines } \\ 4 & \text { Troef } & \times \text { Wagenaar } & \text { and reciprocal, } F_{1}, F_{2}, F_{3} \text { lines } \\ 5 & \text { IVT } 7309 & \times \text { Troef } & \text { no reciprocal, } F_{1}, F_{2}, F_{3} \text { lines } \\ 6 & \text { BBL } & \times \text { BBL } \times \text { Wagenaar) } & \text { and reciprocal, } F_{1}\left(B_{1}\right), F_{2}\left(B_{1}\right) \text { lines }\end{array}$

The $F_{1}$ plants except of $F_{1}\left(B_{1}\right)$ were grown at constant temperatures of 17 and $23{ }^{\circ} \mathrm{C}$ in the greenhouses of the IVT phytotron, to analyse the influence of temperature on string formation, while the $F_{2}, F_{3}$ and the $F_{1}\left(B_{1}\right)$ and $F_{2}\left(B_{1}\right)$ were grown at a constant temperature of $23{ }^{\circ} \mathrm{C}$ to promote string formation. Air humidity usually fluctuated between 50 and $70 \%$. Additional light was given with high-pressure mercury-vapour lamps (Philips HPL/N $400 \mathrm{~W}$ ) for $16 \mathrm{~h}$ a day during winter. The intensity of the additional light was $10 \mathrm{~W} / \mathrm{m}^{2}$.

String was assessed as described by Drijfhout (1970) on a scale 1 to 8 , with one modification: the string value per plant was not determined by averaging the string values of three to four pods, but by taking the highest value of those pods. This gave clearer differences, allowing a better interpretation of the segregations. The plants were classed into three groups, based on the string values of the parents. Plants with values 2.0 and 2.5 were considered stringless, those with 7.5 and 8.0 stringy, and those with values 3.0 to 7.0 intermediate.

\section{Results}

No differences were found between the reciprocal crosses. Hence, they are not mentioned separately in Tables $1-3$.

Table 1 shows the results for string value in $F_{1}$ plants grown at 17 and $23{ }^{\circ} \mathrm{C}$.

Table 1. Mean string values in $F_{1}$ (24-48 plants per temperature) and parent cultivars ( 8 plants).

\begin{tabular}{|c|c|c|c|c|}
\hline \multirow[t]{2}{*}{ Cross and reciprocal or parent } & \multicolumn{2}{|l|}{$17^{\circ} \mathrm{C}$} & \multicolumn{2}{|l|}{$23^{\circ} \mathrm{C}$} \\
\hline & $\begin{array}{l}\text { mean string } \\
\text { value }\end{array}$ & range & $\begin{array}{l}\text { mean string } \\
\text { value }\end{array}$ & range \\
\hline 1 BBL $\times$ Troef & 2.1 & $2.0-2.5$ & 3.2 & $2.0-4.5$ \\
\hline $2 \mathrm{BBL} \times$ Wagenaar & 2.3 & $2.0-3.0$ & 4.0 & $2.5-6.0$ \\
\hline 3 BBL $\times$ IVT 7309 & 2.2 & $2.0-2.5$ & 2.0 & $2.0-2.5$ \\
\hline 4 Troef $\times$ Wagenaar & 5.3 & $4.0-7.0$ & 6.9 & $6.5-7.0$ \\
\hline 5 IVT $7309 \times$ Troef & 4.5 & $3.0-6.0$ & 6.0 & $4.5-7.0$ \\
\hline Bush Blue Lake & 2.0 & 2.0 & 2.1 & $2.0-2.5$ \\
\hline Troef & 4.6 & $3.5-5.5$ & 6.1 & $5.0-7.0$ \\
\hline Wagenaar & 8.0 & 8.0 & 8,0 & 8.0 \\
\hline IVT 7309 & 7.9 & $7.5-8.0$ & 8.0 & 8.0 \\
\hline
\end{tabular}




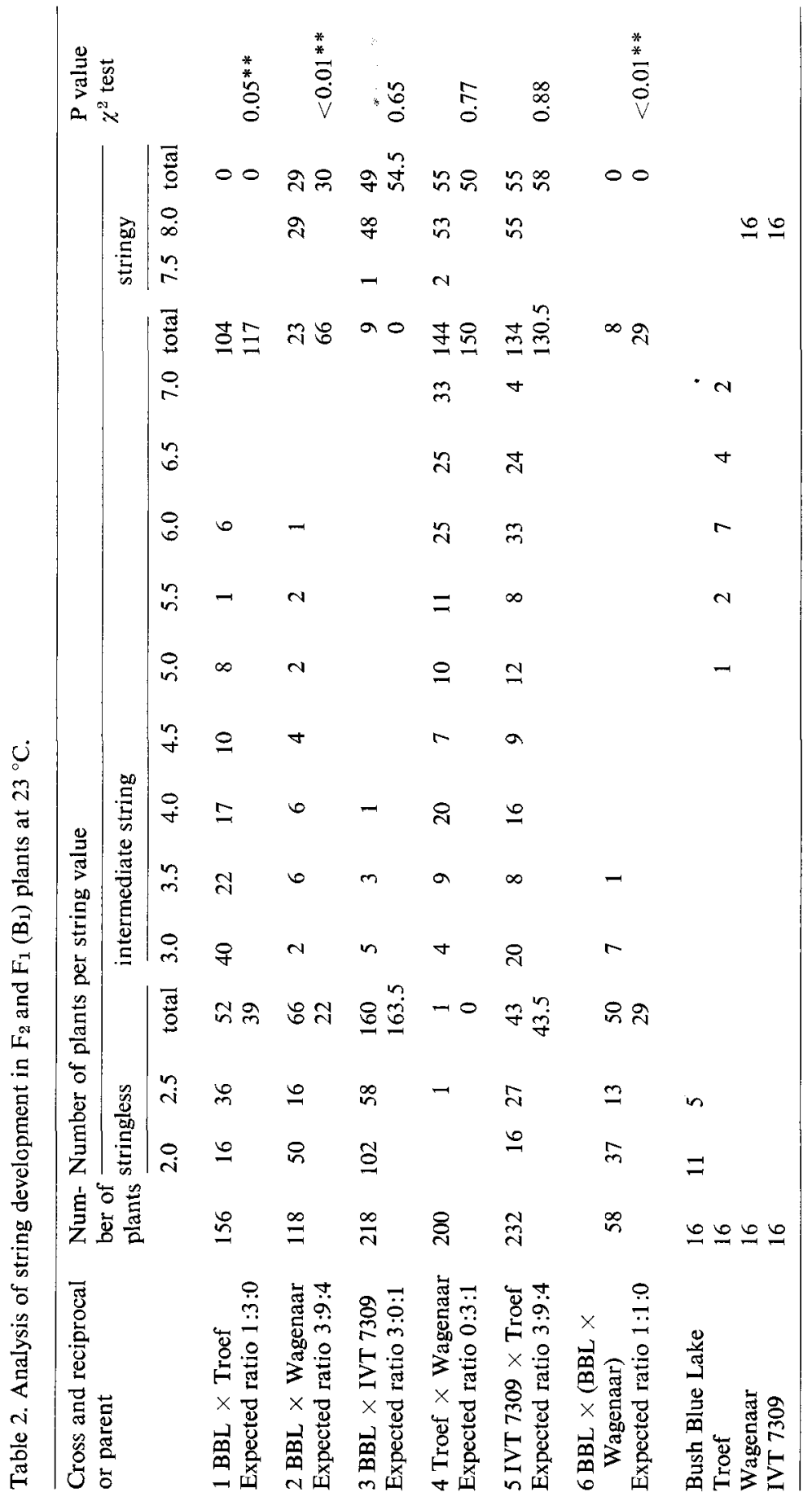

Neth. J. agric. Sci. 26 (1978) 
The results of crosses 2 to 5 confirm published data that the development of a complete string is inherited recessively: no complete string was found in any of the $F_{1}$ plants.

The development of an incomplete string was promoted at $23{ }^{\circ} \mathrm{C}$ in all crosses where 'Troef' or 'Wagenaar' was one of the parents. This temperature-dependent formation of incomplete string seems to be inherited with some degree of dominance. Only in cross 3 did the $F_{1}$ plants remain stringless at both temperatures. For temperature-dependent string formation, 'Troef' and 'Wagenaar' seem to bear one or more dominant genes, which were not present in BBL and IVT 7309.

Table 2 gives the string values of the $F_{2}$ and $F_{1}\left(B_{1}\right)$ plants, the plants being classed into stringless, intermediate and stringy. The segregations obtained were statistically tested against the expected ratios based on the presence of one dominant gene (later indicated as $T s$ ) in 'Troef' and 'Wagenaar', governing the formation of an intermediate string at high temperature in genotypes carrying gene $S t$ for stringlessness.

The segregation stringless, intermediate and stringy in cross 1 gave a poor fit to the expected ratio 1:3:0, because of an excess of stringless plants. This number was also too high in cross 2 , resulting in a poor fit to the expected ratio 3:9:4. The number of stringy plants agreed with expectation. Segregation of cross 3 showed a reasonably good fit to the expected ratio 3:0:1. The nine plants with intermediate string may have been classed incorrectly. The segregation in the $F_{2}$ of cross 4 fitted the expected ratio $0: 3: 1$ very well. The same can be said of cross 5 , tested against

Table 3. Expected genotypic and phenotypic segregation in $F_{2}$ and $F_{3}$ of crosses 2 (BBL $\times$ Wagenaar) and 5 (IVT $7309 \times$ Troef), with assumption of two dominant genes for stringlessness and intermediate string, tentatively designated $S$ and $T$, respectively, leading to the following genotypes for string formation of the parents; BBL SStt; Troef SSTT; Wagenaar ssTT and IVT 7309 sstt. stl $=$ stringless; int $=$ intermediate string; stgy $=$ stringy (complete string).

\begin{tabular}{|c|c|c|c|c|c|c|c|c|c|}
\hline $\begin{array}{l}\text { Generation } \\
\text { genotypes and } \\
\text { phenotypes }\end{array}$ & \multicolumn{9}{|c|}{ Expected segregation in $F_{2}$ and in $F_{3}$ lines } \\
\hline$F_{3}$ genotypes & $1 S S T T$ & $2 S s T T$ & $1 s s T T$ & $2 S S T t$ & $4 S s T t$ & $2 s s T t$ & $1 S S t t$ & $2 S s t t$ & 1 sstt \\
\hline $\mathrm{F}_{2}$ phenotypes & int & int & stgy & int & int & stgy & stl & stl & stgy \\
\hline$F_{3}$ genotypes & $1 S S T T$ & $\begin{array}{l}3 S . T T \\
1 S S T T\end{array}$ & $1 s s T T$ & $\begin{array}{l}1 S S t t \\
3 S S T \text {. }\end{array}$ & $\begin{array}{l}3 \text { S.tt } \\
9 \text { S.T. } \\
3 \mathrm{ssT} \text {. } \\
1 \mathrm{sstt}\end{array}$ & $\begin{array}{l}3 \text { ssT. } \\
1 \text { sstt }\end{array}$ & $1 S S t t$ & $\begin{array}{l}3 \text { S.tt } \\
1 \text { sstt }\end{array}$ & 1 sstt \\
\hline$F_{3}$ phenotypes & 1 int & $\begin{array}{l}3 \text { int } \\
1 \text { stgy }\end{array}$ & 1 stgy & $\begin{array}{l}1 \text { stl } \\
3 \mathrm{int}\end{array}$ & $\begin{array}{l}3 \text { stl } \\
9 \text { int } \\
4 \text { stgy }\end{array}$ & 4 stgy & 1 stl & $\begin{array}{l}3 \text { stl } \\
1 \text { stgy }\end{array}$ & 1 stgy \\
\hline $\begin{array}{l}F_{3} \text { line types } \\
\text { and their ratio }\end{array}$ & $\begin{array}{l}\mathrm{c} \\
1\end{array}$ & $\begin{array}{l}f \\
2\end{array}$ & $\begin{array}{l}\mathrm{g} \\
1\end{array}$ & $\begin{array}{l}\mathrm{b} \\
2\end{array}$ & $\begin{array}{l}\mathrm{e} \\
4\end{array}$ & $\begin{array}{l}\mathrm{g} \\
2\end{array}$ & $\begin{array}{l}\mathrm{a} \\
1\end{array}$ & $\begin{array}{l}d \\
2\end{array}$ & $\begin{array}{l}g \\
1\end{array}$ \\
\hline
\end{tabular}


Table 4. Analysis of string formation in $\mathrm{F}_{3}$ and $\mathrm{F}_{2}\left(\mathbf{B}_{1}\right)$ lines at $23{ }^{\circ} \mathrm{C}$. stl $=$ stringless; int $=$ intermediate (incomplete) string; stgy $=$ stringy (complete string).

\begin{tabular}{|c|c|c|c|c|c|c|}
\hline Cross and reciprocal & $\begin{array}{l}\text { Number } \\
\text { of lines }\end{array}$ & $\begin{array}{l}\text { I } \\
\text { All plants } \\
\text { stl }\end{array}$ & $\begin{array}{l}\text { II } \\
\text { All plants } \\
\text { int or } \\
\text { segregation } \\
\text { stl/int }\end{array}$ & $\begin{array}{l}\text { III } \\
\text { Segreg. } \\
\text { int/stgy or } \\
\text { stl/int/stgy } \\
\text { or stl/stgy }\end{array}$ & $\begin{array}{l}\text { IV } \\
\text { All plants } \\
\text { stringy }\end{array}$ & $\begin{array}{l}P \text { value } \\
\chi^{2} \text { test }\end{array}$ \\
\hline $\begin{array}{l}1 \mathrm{BBL} \times \text { Troef } \\
\text { Expected ratio } 1: 3: 0: 0\end{array}$ & 115 & $\begin{array}{l}24 \\
29\end{array}$ & $\begin{array}{l}91 \\
86\end{array}$ & $\begin{array}{l}0 \\
0\end{array}$ & $\begin{array}{l}0 \\
0\end{array}$ & 0.79 \\
\hline $\begin{array}{l}2 \text { BBL } \times \text { Wagenaar } \\
\text { Expected ratio } 1: 3: 8: 4\end{array}$ & 118 & $\begin{array}{l}6 \\
7\end{array}$ & $\begin{array}{l}24 \\
22\end{array}$ & $\begin{array}{l}58 \\
59\end{array}$ & $\begin{array}{l}30 \\
30\end{array}$ & 0.93 \\
\hline $\begin{array}{l}3 \mathrm{BBL} \times \text { IVT } 7309 \\
\text { Expected ratio 1:0:2:1 }\end{array}$ & 218 & $\begin{array}{l}62 \\
54.5\end{array}$ & $\begin{array}{l}7 \\
0\end{array}$ & $\begin{array}{r}96 \\
109\end{array}$ & $\begin{array}{l}53 \\
54.5\end{array}$ & 0.45 \\
\hline $\begin{array}{l}4 \text { Troef } \times \text { Wagenaar } \\
\text { Expected ratio } 0: 1: 2: 1\end{array}$ & 164 & $\begin{array}{l}0 \\
0\end{array}$ & $\begin{array}{l}49 \\
41\end{array}$ & $\begin{array}{l}79 \\
82\end{array}$ & $\begin{array}{l}36 \\
41\end{array}$ & 0.52 \\
\hline $\begin{array}{l}5 \text { IVT } 7309 \times \text { Troef } \\
\text { Expected ratio } 1: 3: 8: 4\end{array}$ & 232 & $\begin{array}{l}18 \\
14.5\end{array}$ & $\begin{array}{l}44 \\
43.5\end{array}$ & $\begin{array}{l}115 \\
116\end{array}$ & $\begin{array}{l}55 \\
58\end{array}$ & 0.80 \\
\hline $\begin{array}{l}6 \mathrm{BBL} \times(\mathrm{BBL} \times \\
\quad \text { Wagenaar) } \\
\text { Expected ratio } 1: 1: 2: 0\end{array}$ & 58 & $\begin{array}{l}14 \\
14.5\end{array}$ & $\begin{array}{l}16 \\
14.5\end{array}$ & $\begin{array}{l}28 \\
29\end{array}$ & $\begin{array}{l}0 \\
0\end{array}$ & 0.98 \\
\hline
\end{tabular}

ratio 3:9:4. In cross $6, \mathrm{I}$ also found too many stringless plants to fit the expected 1:1:0 ratio.

Thus, the $F_{2}$ segregations of three crosses $(3,4$ and 5$)$ fitted their expected ratios and those of three other crosses $(1,2$ and 6$)$ did not. In the latter, BBL was one of the parents and the poor fit was due to lack of plants with intermediate string and, consequently, an excess of stringless plants.

As the hypothesis of one dominant gene for intermediate string formation fitted the segregation in some crosses but not in others, it was necessary to extend the string analysis to lines of $F_{3}$ and $F_{2}\left(B_{1}\right)$ and to test again the segregations against ratios based on one dominant gene for intermediate string. With that hypothesis, I determined what ratios could be expected.

Tentatively designating the gene for stringlessness $S$ and that for intermediate string $T$ (one-letter symbols to shorten the genotype notations), one can indicate the genotypes for string formation of the parents as follows: BBL, SStt; Troef, SSTT; Wagenaar, ssTT and IVT 7309, sstt. Then $\mathrm{F}_{1}$ BBL $\times$ Wagenaar and IVT $7309 \times$ Troef have the same genotype: SsTt. The segregation, genotypes and phenotypes of the $F_{2}$ and of the $F_{3}$ lines of both crosses are given in Table 3 .

For practical reasons, the seven line types of Table 3 were arranged into four groups, which could be easily distinguished. Group I (Table 4) comprises line type ' $a$ ', group II line types ' $b$ ' and ' $c$ ', group III line types ' $d$ ', 'e' and 'f', and group IV line type ' $\mathrm{g}$ '. Then I could expect a segregation ratio 1:3:8:4 for $F_{3}$ lines of groups I, II, III and IV in crosses 2 and 5. Similarly, ratios 1:3:0:0, 1:0:2:1, 0:1:2:1 and $1: 1: 2: 0$ were expected for crosses $1,3,4$ and 6 , respectively. 
Table 4 shows the numbers of $F_{3}$ or $F_{2}\left(B_{1}\right)$ lines obtained and expected in each group of lines. All segregations were consistent with expectation, pointing to one dominant gene for intermediate string formation in 'Troef' and 'Wagenaar'. I propose to designate this gene $T s$ for temperature-dependent string.

\section{Discussion}

The question arises why the segregations obtained in the $F_{2}$ or $F_{1}\left(B_{1}\right)$ of some crosses (Table 2) did not fit the expected ratics. Crosses 1, 2 and 6 , not giving a satisfactory segregation, are combinations between BBL and a parent supposed to bear gene $T s$. An explanation may be that the genetic background of BBL hinders expression of this gene. This was not found in crosses 4 and 5, suggesting that the genotypes of 'Wagenaar' and IVT 7309, unlike that of BBL, did not inhibit expression.

It was earlier demonstrated (Drijfhout, 1970) that differences in extent of incomplete stringiness occur between cultivars grown at the same temperature. This may also be due to differences in genetic background causing differences in expression of gene $T s$ between cultivars.

If incomplete string be caused by incomplete dominance of $S t$ or be inherited polygenically rather than conditioned by one gene $T s$, we could neither expect segregation of stringless plants in $F_{2}$ of cross 5 (Table 2), nor stringless lines in $F_{3}$ of the same cross (Table 4). Especially the difference in segregation between crosses 4 and 5 strongly suggests one special gene for the development of incomplete string.

\section{Comparison with literature}

Emerson (1902, 1904) worked with two types of crosses. In one type, he found almost completely stringless $\mathrm{F}_{1}$ plants and two categories of plants in the $\mathrm{F}_{2}$, stringless as well as stringy. The $\mathrm{F}_{1}$ plants of the other type of crosses had intermediate string, while the $F_{2}$ segregated into stringless, intermediate and stringy, with an excess of stringless over an 1:2:1 ratio. The first type of cross corresponds with my cross 3 and the other type with cross 2 . There was also an excess of stringless plants in the $\mathrm{F}_{2}$ of the latter cross. Emerson explained his excess of stringless plants by misclassification, but according to my results, it might have been due to incomplete expression of gene $T s$. From the $\mathrm{F}_{3}$ results, he also assumed a monogenic inheritance for the second type of crosses, but this might be because of his small number (28) of $F_{3}$ lines and because he considered lines only as segregating if plants with complete string were found as well as others, not taking into account that lines might also segregate into stringless and intermediate.

In view of my results I agree with Joosten (1927) that a plant does not inherit a certain string formation but the potential for string formation, its actual development depending on climatic conditions. However, this is only true of the inheritance of incomplete string, formation of complete string is not influenced by temperature.

Currence (1930) explained his phenotypic $F_{2}$ ratio of 3:13 for stringless to stringy and genotypic 1:8:7 ratio for stringless to segregating to stringy by assuming a gene $T$, suppressing the action of gene $S$ for stringlessness and resulting in three 


\section{TEMPERATURE-DEPENDENT STRING FORMATION IN COMMON BEAN}

genotypes for stringiness, SSTT, ssTT and sstt, and one genotype SStt for stringlessness. His explanation comes close to the one I propose, but he neither distinguished incomplete and complete stringiness nor discovered the influence of temperature. As his symbols $S$ and $T$ were not included in the gene list of common bean (Bean Germ Plasm Committee, 1965), I do not use them, but St of Prakken (1934) and propose a new symbol $T$ s for the gene governing incomplete string formation because $T$ was used for another character.

Prakken (1934) studied the string formation of the cross Fijne Tros $\times$ Wagenaar and assumed intermediary inheritance of string development, governed by gene $S t$. That cross can probably be compared with my cross 4 , Troef $\times$ Wagenaar, although the level of incomplete string formation of 'Fijne Tros' was lower than that of 'Troef'. Prakken found a phenotypic 3:1 (not pure stringy to stringy) and a genotypic 1:2:1 ratio (not pure stringy to segregating to stringy) in the $F_{2}$. I obtained the same ratios in cross 4 . As gene $T s$ was present in both parents, a monogenic segregation was found.

The 9:7 ratio obtained by Wade \& Zaumeyer (1940) for stringless to stringy in the $F_{2}$ of their cross is difficult to compare with any of my $F_{2}$ ratios because of different classification of the string. They did not distinguish incomplete and complete string formation and used unboiled pods to determine the strength of the string, unlike Prakken (1934) and myself.

Conclusions. In view of the inhibiting influence of BBL, the segregations obtained in the different generations of crosses 1 to 6 can be sufficiently explained by the action of two genes for string development: (1) gene $S t$, of which the dominant allele governs stringlessness, and the recessive alleles condition complete string; (2) a gene proposed to denote as $T s$, of which the dominant allele governs incomplete string development at high temperature in genotypes with dominant allele $S t$.

Extent of incomplete stringiness increases with temperature but may be inhibited by the genetic background of the plant.

\section{References}

Bean Germ Plasm Committee, 1965. List of genes of Phaseolus vulgaris L. A. Rep. Bean Improvement Coop. 8: 4-20.

Currence, T. M., 1930. Inheritance studies in Phaseolus vulgaris. Tech. Bull. Univ. Minn. agric. Exp. Stn 68; 28 pp.

Drijfhout, E., 1970. Influence of temperature on string formation of beans (Phaseolus vulgaris L.). Euphytica 19: 145-151.

Emerson, R. A., 1902. Preliminary account of variation in bean hybrids. A. Rep. Univ. Nebr. agric. Exp. Stn 15: 30-49.

Emerson, R. A., 1904. Heredity in bean hybrids (Phaseolus vulgaris). A. Rep. Univ. Nebr. agric. Exp. Stn 17: 33 .

Joosten, J. H. L., 1927. Een onderzoek naar het kenmerk der draadloosheid bij verschillende bonerassen. Meded. LandbHogesch. Wageningen 31; 49 pp.

Prakken, R., 1934. Inheritance of colours and pod characters in Phaseolus vulgaris L. Martinus Nijhoff, The Hague, 293 pp.

Wade, B. L. \& W. J. Zaumeyer, 1940. Genetic studies of resistance to alfalfa mosaic virus and of stringiness in Phaseolus vulgaris. J. Am. Soc. Agric. 32: 127-134. 